\title{
Welfare Potential of Zakat: An Attempt to Estimate Economy wide Zakat Collection in Pakistan
}

\author{
SALMAN AHMED SHAIKH
}

\section{INTRODUCTION}

In Pakistan, Naveed and Ali (2012) in a most recent study conclude that as many as 58.7 million people in Pakistan are living in multidimensional poverty with 46 percent of the rural population and 18 percent of the urban households falling below the poverty line. It is natural to ask what the government is doing for these poor people and how much it can expend to end extreme poverty in Pakistan. If we look at the fiscal position of the government, we see that Pakistan has a very low tax to GDP ratio, i.e. 9 percent. As a result of low tax to GDP ratio and high current expenditure, the government is suffering from a large budget deficit. Often, the development spending is curtailed to contain the large budget deficit due to high non-discretionary current expenditures in debt servicing and security expenditure.

Expenditure on health and education is not even 5 percent of GDP in Pakistan. Due to such a low expenditure on developing human capital and maintaining health of the masses, poor people remain uneducated and unhealthy and hence they find it very difficult to get out of the poverty trap.

After deregulation of the banking sector in the 90s, a lot of commercial banks started operations in the private sector. But, their outreach is very low in rural areas where most of the poverty exists. Microfinance penetration is also very low in Pakistan. According to Pakistan Bureau of Statistics, 2.35 million people out of 58.7 million poor people are served with Microfinance. It shows that only 4 percent of the potential target market is currently served with Microfinance. Hence, there is a need to mobilise more resources to end extreme poverty in Pakistan. If we compute the crude poverty gap by multiplying the number of estimated poor people in Pakistan with the minimum annual income required to qualify as a non-poor according to dollar a day poverty line, we see that Pakistan requires around Rs $2,142.5$ billion or approximately 7 percent of GDP to have zero poverty. However, this crude measure is unrealistic since it assumes that every poor person has zero income. But, this crude measure gives us an approximate conservative requirement of funds to end poverty in Pakistan.

In this paper, we discuss how the institution of Zakat can help in generating development funds and contribute in reducing poverty. We estimate the potential aggregate Zakat collectible in Pakistan economy and compare it with the poverty gap.

Salman Ahmed Shaikh <islamiceconomicsproject@ gmail.com> is PhD Scholar in Economics, Pakistan Institute of Development Economics, Islamabad. 
The analysis will show the potential of the institution of Zakat to contribute in ending extreme poverty in Pakistan.

We proceed as follows. In Section 2, we present brief review of theoretical and empirical literature on Zakat. In Section 3, we present the effects of Zakat on wealth redistribution. In Section 4, we discuss issues in the estimation of Zakat. In Section 5, we present the estimation results. Finally, in Section 6, we discuss the economic effects of the institution of Zakat on business cycle stabilisation, tax rate smoothing, market competitiveness and the flow of investment.

\section{BRIEF LITERATURE REVIEW}

Zakat is an important institution in an Islamic economic framework for poverty alleviation and economic welfare. In Islam, Zakat is a religious obligation to pay a part of wealth and production to the government. As per Islamic injunctions, the government has to spend the Zakat funds on specified heads mentioned in Chapter Tauba, verse 60 . Wahid (1986) explains that Zakat is a compulsory payment on the part of Muslims as a share to the poor, having a wide variety of economic and social ramifications.

In its economic character, Zakat is a combination of a net worth levy and a production levy. In early empirical literature on welfare potential of Infaq to alleviate poverty in Pakistan, Malik, et al. (1994) use micro data to establish that Infaq does have significant impact on reducing poverty gap. In a recent empirical study for OIC countries, Shirazi and Amin (2009) estimate the resources required for poverty elimination under US $\$ 1.25$ a day and US $\$ 2.0$ a day respectively. Their estimates for Pakistan suggest that Pakistan needs 1 percent of GDP for poverty elimination under US $\$ 1.25$ a day and needs 6.77 percent of GDP for poverty elimination under US \$2 a day. For Pakistan, Kahf (1989) use different Zakat categories and according to his estimate, Zakat collection can be between 1.6 percent of GDP to 4.4 percent of GDP.

In a more recent study, Azam, et al. (2014) in an empirical study for Pakistan establish that Zakat significantly enhances the welfare of the households. M. Akram and Afzal (2014) in an empirical study for Pakistan argue that Zakat disbursement among the poor, needy, destitute, orphans and widows has played a significant role in poverty alleviation. Their results show that there is an inverse relationship between poverty and Zakat disbursement both in the short run and in the long run.

In another empirical study for Bangladesh, Hassan and Jauanyed (2007) estimate that Zakat funds can replace the government budgetary expenditures ranging from 21 percent of Annual Development Plan (ADP) in 1983-84 to 43 percent of ADP in 20042005. For Malaysia, Sadeq (1996) finds that about 73 percent of the estimated potential Zakat collection will be needed annually to change the status of hard-core households to a status of non-poor households in Malaysia. Ibrahim (2006) contends in an empirical study for Malaysia that Zakat distribution reduces income inequality. His analysis reveals that Zakat distribution reduces poverty incidence, reduces the extent of poverty and lessens the severity of poverty. Firdaus, et al. (2012) estimate the potential of Zakat in Indonesia by surveying 345 households. Their results show that Zakat collection could reach 3.4 percent of Indonesia's GDP.

Some studies also show the comparative potential of Zakat as a superior tool for poverty alleviation. Debnath, et al. (2013) assess the effectiveness of Zakat as an 
alternative to microcredit in alleviating poverty in Bangladesh. Through the Propensity Score Matching (PSM) techniques, the study reveals that the impact of Zakat scheme has proven greater than the microcredit programs. Besides that, the study also highlights that Zakat scheme significantly increases both income and expenditure of the recipients in comparison to the microcredit programs.

Some studies like Nadzri, et al. (2012) recommend integrating the various poverty alleviation and redistribution tools for creating synergies. The effectiveness of Zakat institutions may improve by collaborating with other institutions such as Microfinance institutions. Shirazi (2014) suggests that the institutions of Zakat and Waqf need to be integrated into the poverty reduction strategy of the IDB member countries. The proceeds of these institutions should be made as part of their pro-poor budgetary expenditures. Hassan (2010) suggests a model which combines Islamic Microfinance with two traditional Islamic tools of poverty alleviation such as Zakat and Waqf in an institutional setup. Hassan (2010) argues that the poor borrowers will have less debt burden as their capital investments will be partly met by funds from Zakat that does not require any repayment.

The institution of Zakat is very dynamic and flexible. In Umer (rta) and Abu Bakar (rta) period of government, Zakat was collected by the government. But, in Usman (rta) period, people were allowed to pay Zakat privately [Kuran (2003)]. Horses were exempted from Zakat in Prophet's time, but, Umer (rta) brought them in the Zakat net in His period. Similarly, Mahmud (2001) argues that the institution of Zakat is flexible to a certain degree as Umer (rta) levied Zakat on horses and skins and at the time when Arab was hit with a drought and famine, he exempted poor from Zakat and suspended Zakat from the rich. Usman (rta) also levied Zakat on the production in forests which was not the case in the earlier period [Nadvi (1996)]. Hence, a policy maker in a modern economy can use this institution flexibly to maximise the welfare benefits of the Zakat system.

Nevertheless, Zakat is not collected by the government nowadays in most countries and is not considered a compulsory payment to the government [Powell (2009)]. Abu Bakar, et al. (2007) argue that there may be lack of proper implementation of Zakat in Muslim countries which limits the success of the noble aims of Zakat. Yusoff (2011) urges that every Muslim country must organise Zakat collection and Zakat spending in the most effective and efficient manner. Azam, et al. (2014) also suggest that there is a need to institutionalise the Zakat collection system to increase the overall Zakat collection.

One of the potential reasons for this state of affairs is that the mainstream Islamic scholarship allows taxes to be levied other than Zakat for mobilising public finance. Maududi (1970) argues that Zakat is a religious obligation and is not a substitute of tax. Taxes other than Zakat can be imposed in an Islamic economy if these taxes are levied by the legislative council and used for public welfare. He contends that the taxes discouraged in Ahadith are those which were imposed by the autocratic kings for their own lavish consumption and this kind of usurpation of public property was discouraged in Islam.

Apart from weak administration and implementation of Zakat system, another reason why Zakat collection is low at the central level in Pakistan is that there is a big and 
growing trust deficit between the central government and the people. This trust deficit is reflected in the meager Zakat collection at the government level. As can be seen from Figure 1, Zakat collection and its disbursement is very low in Pakistan at the government level.

Fig. 1. Zakat Receipts (in Million Rs)

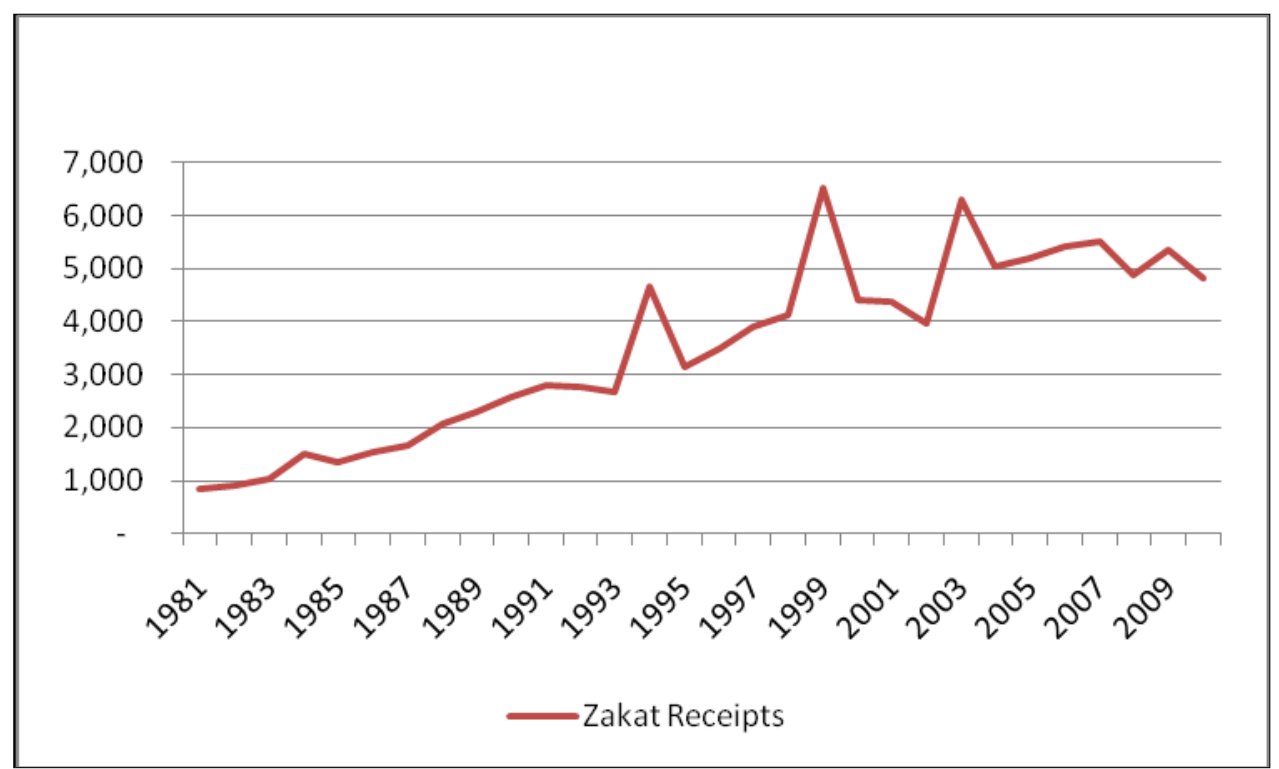

Source: Pakistan Bureau of Statistics.

In this study, we attempt to estimate potential Zakat collection at the economy wide level to explore the welfare potential of the institution of Zakat.

\section{MATHEMATICAL COMPUTATION OF ZAKAT}

In this section, we present a simple mathematical representation of the effects of Zakat on wealth redistribution. To begin with, we can represent lifetime wealth Zakat function for an individual ' $\mathrm{i}$ ' as:

$$
Z_{i}=\sum_{t=1}^{n} 0.025\left(N Z W_{t}\right)
$$

Here,

$Z_{i}$ is Zakat liability of an individual ' $\mathrm{i}$ '.

Time period ' $\mathrm{t}$ ' runs from $\mathrm{t}=1$ (current time period) to ' $\mathrm{n}$ ' (terminal point of life). $N Z W_{t}$ represents net Zakat wealth. It is computed as $\left(W_{t}-N_{t}\right)$.

Where $W_{t}$ is the gross amount of wealth and $N_{t}$ is the value of Nisaab amount.

Nisaab is the minimum threshold level of wealth which is not subject to Zakat.

Zakat function of an economy for a particular year can be represented as:

$$
Z_{T}=\sum_{i=1}^{n} 0.025\left(N Z W_{i}\right)
$$


For a particular individual 'i', net Zakat wealth at a point in time is given by:

$$
W_{t}=I_{t}-0.025\left(N Z W_{t-1}\right)+W_{t-1}-C_{t}
$$

Here,

$I_{t}$ is the income of individual ' $i$ ' in time period ' $t$ '.

$N Z W_{t-1}$ is the base of wealth that will be used for Zakat deduction.

$W_{t-1}$ is the wealth of individual ' $i$ ' in the previous time period.

$C_{t}$ is the consumption in time period ' $t$ '.

Simplifying the above equation, we get:

$$
\begin{aligned}
& W_{t}=I_{t}-0.025\left(W_{t-1}-N_{t-1}\right)+W_{t-1}-C_{t} \\
& W_{t}=I_{t}-0.025 W_{t-1}+W_{t-1}+0.025 N_{t-1}-C_{t} \\
& W_{t}=I_{t}+0.975 W_{t-1}+0.025 N_{t-1}-C_{t}
\end{aligned}
$$

Expanding it iteratively forward, we get

$$
\begin{aligned}
W_{t+1}= & I_{t+1}+W_{t}-0.025\left(W_{t}-N_{t}\right)-C_{t+1} \\
W_{t+1}= & I_{t+1}+0.975 W_{t}+0.025 N_{t}-C_{t+1} \\
W_{t+1}= & I_{t+1}+0.975\left(I_{t}+0.975 W_{t-1}+0.025 N_{t-1}-C_{t}\right)+0.025 N_{t}-C_{t+1} \\
W_{t+1}= & I_{t+1}+0.975 I_{t}+0.950625 W_{t-1}+0.024375 N_{t-1}+0.025 N_{t}- \\
& 0.975 C_{t}-C_{t+1}
\end{aligned}
$$

It can be seen that the wealth function will diminish wealth overtime and overall wealth can only increase with increase in income, labor plus non-labor.

\section{ISSUES IN THE ESTIMATION OF ZAKAT}

Shirazi and Amin (2009) argue that since there is no agreement among the scholars on the new wealth that may be brought under the Zakat net, there is an urgent need for the general agreement on the definition of the items, which may be taken as Zakatable items. This requires Ijmah of the ulama and other contemporary scholars on the issue.

On the need for extending the Zakat net by including all forms of wealth and produce, Qardawi (1999, p. 333) applies the methodology of qiyas (analogical reasoning) and reasons that the emerging and increasing types of wealth in the modern times such as bank deposits and financial securities like shares and bonds are also Zakatable [Qaradawi (1999)]. Abu Bakar, et al. (2007) also suggest that the 'illah' for Zakatability should no longer be productive property, but any property which is in excess of one's personal use.

That is why; wealth or assets subject to Zakat should include cash in hand or at bank, gold and silver, held-for trade inventory, real estate purchased for the purpose of resale and all types of financial investments in stocks, bonds, debentures, national saving schemes and mutual funds.

Likewise, production is not limited to agriculture nowadays. The major part of production comes from industries as well as services sector. Therefore, income from the industrial production could also be taxed just like agriculture. Services income could also be taxed on the same principle.

To summarize, Zakat should be levied as per the ceiling rates defined for each category of wealth or production. The classification is as follows: 
- 2.5 percent on cash, wholesale value of held for trade inventory and wealth in excess of need. It is payable once a year at a particular set date.

- 5 percent on production value or any other income earning activity using both labour and capital. It is charged at the completion of the production process or realisation of income. Modern day analogous extension could be to use that to collect Zakat from manufacturing and service industries.

- 10 percent on production or any other income earning activity using either labour or capital. It is charged at the completion of the production process or realisation of income. Modern day analogous extension could be to use that to collect Zakat from income of self-employed practitioners, like lawyers, doctors, consultants, teachers or engineers. It could also include income from such sources where only capital is invested like equity investments in stocks, mutual funds and Real Estate Investment Trusts (REITs) etc.

- 20 percent on production using neither labour nor capital. This is applicable on treasure or any other natural gift obtained without using labour or capital. Modern day analogous extension could be to use that to collect Zakat from royalty income etc.

The derivation for production tax comes from the fact that the rain-fed lands were subject to a 10 percent production tax whereas, the irrigated land (which had to be provided with capital) were subject to a 5 percent production tax in Prophet's time.

Next, we discuss another important question that whether the investment in financial instruments shall be subject to wealth Zakat on total investment value or only the income from such financial investments shall be subject to income Zakat. Khan (2005) contends that investment in stocks should be interpreted as any other investment with some means of earning income. Investment in a stock is a means of earning dividend income or capital gains. Just like means of production/income are exempted from Zakat, investment in stocks should be exempted from wealth Zakat. Therefore, any income arising from investment in stocks must be subject to income Zakat. Similarly, this argument could be extended to introduce income Zakat on mutual funds, investment in National Savings Schemes (NSS), debentures, bonds etc. Furthermore, if a real estate is leased, the real estate becomes the means of earning rent for the owner. Hence, income Zakat could also be introduced on rental income.

However, if employees or directors are given bonuses in the form of stock ownership, they will have to pay 5 percent Zakat on income from investment in stocks. It is due to the fact that in this case, the participation in the business venture is not only by way of providing capital, but also by providing labour. One crucial advantage to this is that the directors will be willing to make the company grow and own its stock so as to benefit not only from dividend/capital gains, but also be able to pay less tax on that income i.e., 5 percent rather than 10 percent. This will also solve the agency problem as well in an effective way.

\section{ESTIMATION OF ZAKAT}

Starting with agriculture, we first present some data that gives us an idea of how much Zakat could be collected both with current level of production and with enhanced 
level of production with efficient utilisation of land. It can be seen from the following data that land size of 8.31 million hectares is unutilised cultivable land in Pakistan. Using the principle of "Ahya-al-Muat" (cultivating idle land), we assume that this land shall be fully utilised through suitable land reforms. If agriculture's share is approximately 21 percent of GDP utilising 22.04 million hectares, an addition in production through utilisation of that idle farm land can be computed assuming constant returns to scale on average.

Table 1

Land Utilisation (Million Hectares)

\begin{tabular}{ccc}
\hline Year & Total Area Cultivated & Cultivable Waste \\
\hline 1991 & 20.96 & 8.85 \\
1992 & 21.06 & 8.86 \\
1993 & 21.4 & 8.83 \\
1994 & 21.51 & 8.74 \\
1995 & 21.55 & 8.91 \\
1996 & 21.68 & 8.87 \\
1997 & 21.98 & 9.06 \\
1998 & 21.96 & 9.15 \\
1999 & 21.93 & 9.23 \\
2000 & 21.96 & 9.09 \\
2001 & 22.13 & 9.17 \\
2002 & 22.27 & 8.95 \\
2003 & 22.21 & 8.95 \\
2004 & 22.12 & 9.1 \\
2005 & 22.13 & 8.94 \\
2006 & 22.65 & 8.21 \\
2007 & 21.88 & 8.3 \\
2008 & 21.28 & 8.18 \\
2009 & 21.38 & 8.19 \\
2010 & 21.4 & 8.09 \\
2011 & 22.03 & 8.98 \\
2012 & 22.04 & 8.31 \\
2013 & 22.04 & 8.31 \\
\hline Source: Ministry of Food, Agriculture and Livestock. &
\end{tabular}

\subsection{Calculation of Nisaab for Individuals (Exemption Amount)}

In Table 2, we show Nisaab computation. Nisaab amount is computed by taking the market value of 612 grams of silver in Pakistan as on March 18, 2014. 
Table 2

Nisaab Computation

Price of Silver (10 Grams) in Rs

\subsection{Zakat Computation on Gold}

It is difficult to obtain micro data on gold holdings in Pakistan from aggregate indicators. For this reason, we conducted a survey of approximately 100 families in Karachi. Based on the reported asset holdings, we estimate that given a family owns a housing unit with minimum 3 rooms in an urban locality, it will possess on average 200 grams of gold. Most definitely, some families will own more or less than this; but, for Pakistan, this assumption seems to be close to the mean value based on the survey results. With our estimates, we arrive at Rs 2.78 trillion as the Zakatable value of gold in Pakistan as reported in Table 3.

Table 3

Estimation of Zakat in Gold

\begin{tabular}{lc}
\hline Total Housing Units in Pakistan (Source: WB 2009) & $20,480,000$ \\
Total Housing Units in Pakistan (2014 Estimated) & $22,000,000$ \\
Share of Urban Dwellings & $32.20 \%$ \\
Share of Houses with Minimum 3 Rooms in Urban Areas & $37.95 \%$ \\
Total Houses (Urban) with Minimum 3 Rooms (Source: PBS) & $2,688,378$ \\
Per Housing Unit Gold Holdings in Grams & 200 \\
Amount of Gold in Grams & $537,675,600$ \\
Price of 1 gram Gold (As on March 18, 2014) & Rs 5,168 \\
Amount of Gold Value (in million Rs) & Rs 2,778,707 \\
\hline
\end{tabular}

\subsection{Zakat Computation on Tradable Inventory}

It is very hard to compute the value of unsold inventory at a particular date. Wholesale and retail trade comprises 17 percent of total national income in Pakistan. Moreover, most of the informal sector is engaged in trading and that contribution does not usually show up in national income accounts.

To get a minimum estimate, we take the head 'change in inventories' from national income accounts. In national income accounting, 'inventory investment' represents value of production in a particular year that remains unsold during that year. It is assumed that the firm has itself purchased unsold inventory from itself. However, that figure in national income accounts gives an estimate of tradable inventory for production that had taken place only in 
that year. The actual tradable inventory could be much more than that. In Table 4 as well as in 5 , we report the estimation of Zakat on tradable inventory. We apply 2.5 percent rate of Zakat on the estimated value of tradable inventory.

\subsection{Zakat Computation on Value of Produce}

If potential Zakat collection is estimated using the classical method in which all liquid holdings like cash, bank deposits, equity investments, mutual fund investments, annuities investments and fixed income securities investments are subject to wealth Zakat, the estimation of Zakat is shown in Table 4. For estimating the value invested in stocks, mutual funds, national saving schemes, we take KSE market capitalisation, Assets Under Management (AUM) of mutual funds and outstanding balance of national saving schemes respectively.

However, if our proposal is applied, the results will be different as reported in Table 5. In our proposal, invested capital will be considered a means of earning income and only income from that invested capital shall be subject to Ushr (i.e. a 10 percent levy).

Likewise, produce from agriculture, industry and services shall also be subject to a 5 percent levy or Ushr. The production from irrigated lands shall be subject to a 5 percent levy. The production from rain-fed lands shall be subject to Ushr (i.e. a 10 percent levy).

Since industries (manufacturing as well as services) are both labor and capital intensive, industrial production shall be subject to a 5 percent levy.

\subsection{Zakat on Livestock}

There are different rates of Zakat on different types of livestock. But, at least 2.5 percent Zakat is applied on different categories of livestock. Hence, we apply the conservative rate of 2.5 percent on livestock.

\subsection{Estimation of Aggregate Zakat}

\subsubsection{Classical Method}

In Table 4, we show the computation of aggregate Zakat from the classical method. Data on mutual funds assets is taken from Mutual Funds Association of Pakistan (MUFAP). Data on KSE market capitalisation is taken from Karachi Stock Exchange (KSE). Data on currency in circulation, outstanding volume of NSS, livestock population and agricultural produce is taken from Pakistan Bureau of Statistics (PBS).

Lastly, we add import duty in the estimation of potential source of public revenues. Umar (rta) charged a similar levy on imported goods into the state as was charged by other regions on the exported goods originating from the Islamic state. This method of reciprocal tariffs is analogous to the Most Favoured Nation (MFN) principle in World Trade Organisation (WTO). For potential import duty collection, we use the last reported weighted average import tariff rate in Pakistan, i.e. 9.53 percent. 
Table 4

Estimation of Zakat Based on Classical Approach

\begin{tabular}{|c|c|c|c|c|}
\hline Report Date & Category & Quantity & $\begin{array}{l}\text { Amount } \\
\text { (Mln Rs) }\end{array}$ & $\begin{array}{c}\text { Zakat } \\
\text { Collectible } \\
\text { (Mln Rs) }\end{array}$ \\
\hline \multicolumn{5}{|c|}{ Zakat on Wealth } \\
\hline & Gold & & $2,778,707$ & \\
\hline End-Jun 2013 & Currency in Circulation & & $1,938,222$ & \\
\hline End-Jun 2013 & Deposits in Personal Category & & $3,516,096$ & \\
\hline 15-Mar-14 & KSE Market Capitalisation & & $6,277,437$ & \\
\hline 18-Mar-14 & Open End Funds & & 378,187 & \\
\hline 18-Mar-14 & Closed End Funds & & 19,894 & \\
\hline 18-Mar-14 & Pension Schemes & & 6,275 & \\
\hline End-Jun 2012 & NSS & & $1,676,361$ & \\
\hline 14-Mar-14 & Foreign Exchange Reserves & & 964,000 & \\
\hline End Jun 2013 & Changes in Stocks/Inventories & & 366,545 & \\
\hline End-Jun 2013 & Livestock Value (Cattle at Rs 40,000/Unit) & $38,300,000$ & $1,532,000$ & \\
\hline End-Jun 2013 & Livestock Value (Buffalo at Rs 40,000/Unit) & $33,700,000$ & $1,348,000$ & \\
\hline End-Jun 2013 & Livestock Value (Sheep at Rs 10,000/Unit) & $28,800,000$ & $1,152,000$ & \\
\hline End-Jun 2013 & Livestock Value (Goat at Rs 10,000/Unit) & $64,900,000$ & $2,596,000$ & \\
\hline \multirow[t]{5}{*}{ End-Jun 2013} & Livestock Value (Camel at Rs 40,000/Unit) & $1,000,000$ & 40,000 & \\
\hline & Less: Nisaab Amount ( $\mathrm{P}_{\mathrm{MNA}} \mathrm{x}$ MNA) & & 492,204 & \\
\hline & Net Amount Subject to Zakat & & $24,097,521$ & \\
\hline & Total Wealth Zakat & & & 602,348 \\
\hline & Zakat on Produce & & & \\
\hline End-Jun 2013 & Produce on Rain-fed Land & & 780,904 & 78,090 \\
\hline \multirow[t]{2}{*}{ End-Jun 2013} & Produce on Irrigated Land & & $2,342,711$ & 117,136 \\
\hline & \multicolumn{3}{|c|}{ Total Zakat Collection by Classical Method } & 797,664 \\
\hline \multirow[t]{2}{*}{ End-Jun 2013} & Import Duty on Tariff & & $4,481,560$ & 427,092 \\
\hline & \multicolumn{3}{|c|}{ Total Zakat Collection by Classical Method and Import Tariff } & $1,224,756$ \\
\hline
\end{tabular}

\subsubsection{Proposed Method}

In Table 5, we show the computation of aggregate Zakat from the proposed method. In this method, the only change is that income from invested capital in bank accounts, stock market, mutual funds and national savings scheme is subject to Ushr (i.e. a 10 percent levy). 
Table 5

Estimation of Zakat Based on Proposed Approach

\begin{tabular}{|c|c|c|c|c|}
\hline Report Date & Category & Quantity & $\begin{array}{l}\text { Amount } \\
\text { (Mln Rs) }\end{array}$ & $\begin{array}{c}\text { Zakat } \\
\text { Collectible } \\
\text { (Mln Rs) }\end{array}$ \\
\hline & Zakat on Wealth & & & \\
\hline Estimated (2014) & Gold & & $2,778,707$ & \\
\hline End-Jun 2013 & Currency in Circulation & & $1,938,222$ & \\
\hline 14-Mar-14 & Foreign Exchange Reserves & & 964,000 & \\
\hline End Jun 2013 & Changes in Stocks/Inventories & & 366,545 & \\
\hline End-Jun 2013 & Livestock Value (Cattle at Rs 40,000/Unit) & $38,300,000$ & $1,532,000$ & \\
\hline End-Jun 2013 & Livestock Value (Buffalo at Rs 40,000/Unit) & $33,700,000$ & $1,348,000$ & \\
\hline End-Jun 2013 & Livestock Value (Sheep at Rs 10,000/Unit) & $28,800,000$ & $1,152,000$ & \\
\hline End-Jun 2013 & Livestock Value (Goat at Rs 10,000/Unit) & $64,900,000$ & $2,596,000$ & \\
\hline \multirow[t]{6}{*}{ End-Jun 2013} & Livestock Value (Camel at Rs 40,000/Unit) & $1,000,000$ & 40,000 & \\
\hline & Less: Nisaab Amount ( $\mathrm{P}_{\mathrm{MNA}} \mathrm{x}$ MNA) & & 492,204 & \\
\hline & Net Amount Subject to Zakat & & $12,223,270$ & \\
\hline & Total Wealth Zakat & & & 305,582 \\
\hline & Zakat on Income/Production & & & \\
\hline & Ushr & & & \\
\hline End-Feb 2014 & Deposits in Personal Category & & $3,516,096$ & 20,956 \\
\hline 18-Mar-14 & KSE Market Capitalisation & & $6,557,000$ & 131,140 \\
\hline 18-Mar-14 & AUM in Open End Funds & & 378,187 & 4,916 \\
\hline 18-Mar-14 & AUM in Closed End Funds & & 19,894 & 259 \\
\hline 18-Mar-14 & AUM in Pension Schemes & & 6,275 & 82 \\
\hline End-Jun 2012 & Outstanding Amount in NSS & & $2,011,263$ & 20,113 \\
\hline \multirow[t]{2}{*}{ End-Jun 2013} & Produce on Rain-fed Land & & 780,904 & 78,090 \\
\hline & Production Value / Income Subject to 5\% & & & \\
\hline End-Jun 2013 & Produce on Irrigated Land & & $2,342,711$ & 117,136 \\
\hline End-Jun 2013 & Ushr on Industry & & $4,605,762$ & 230,288 \\
\hline \multirow[t]{2}{*}{ End-Jun 2013} & Ushr on Services & & $13,054,909$ & 652,745 \\
\hline & Total Zakat Collection & & & $1,561,307$ \\
\hline \multirow[t]{2}{*}{ End-Jun 2013} & Import Duty on Tariff & & $4,481,560$ & 427,092 \\
\hline & Total Zakat Collection and Import Tariffs & & & $1,988,399$ \\
\hline
\end{tabular}

The weighted average deposit rate of 5.96 percent is used from the data provided by State Bank of Pakistan (SBP) for the period of the study. Hence, we apply Ushr on this average yearly return on bank deposits in the personal category. Average yearly growth in KSE 100 index value has been around 20 percent during 1998-2013. Hence, we apply Ushr on this average yearly return. Since mutual funds try to have diversified portfolio with income and equity financial securities, we apply Ushr on average return on KSE 100 during 1998-2013 and weighted average deposit rate. Lastly, since NSS are usually long term savings instruments, we apply Ushr on an average mean return of 10 percent on NSS securities.

To deduct the Nisaab amount at the aggregate level, we have to make an estimate of how many people have the wealth from various sources mentioned above exceeding Nisaab amount. We take a conservative route to assume that people in the top income quintile of the labor force will have wealth exceeding Nisaab amount. If we assume that top 20 percent people in the labor force have the wealth exceeding Nisaab amount; then: 
$\mathrm{P}_{\mathrm{MNA}}=$ Number of people in the labor force $\mathrm{x} 20$ percent

$\mathrm{P}_{\mathrm{MNA}}=60,000,000 \times 20$ percent

$\mathrm{P}_{\mathrm{MNA}}=12,000,000$

MNA = Rs. 41,017 (as calculated above)

From Zakatable assets that are subject to wealth Zakat, we have to deduct the product $\left[\mathrm{P}_{\mathrm{MNA}} \times \mathrm{MNA}\right]$,

$\mathrm{P}_{\mathrm{MNA}} \times \mathrm{MNA}=\mathrm{Rs} 492.2$ Billion

We make this deduction in the computation of Zakatable value of assets and wealth.

Hence, the total Zakat collection comes to be close to 7 percent of GDP in Pakistan. Since the heads of Zakat include poor and destitute, it will force the government to use this spending on the welfare of the poor masses and by establishing educational and health institutions for the poor in the society. This can help the government to scale up its welfare spending on the poor. If we use the simple methodology adopted by Ahmed (2004), the potential Zakat collection fulfills the need of actual funds required for poverty alleviation. Ahmed (2004) uses a conservative crude measure of poverty gap by multiplying the number of poor people with the average minimum annual income of $\$ 365$ or dollar a day per non-poor person. This is a conservative measure since it assumes that poor people have zero annual income [Shirazi and Amin (2009)].

\section{ECONOMICS OF THE PROPOSED ZAKAT BASED TAXATION SYSTEM}

Adam Smith in his monumental work "An inquiry into the nature and causes of wealth of nations" discusses the cannons of taxation. The proposed Zakat based taxation system goes very well with Adam Smith's cannons of taxation. It has a proportional tax and it does not tax production heavily. It is also simple and certain. It is convenient to collect and more so, because it is a religious obligation than just an involuntary tool for fetching wealth. It only taxes those who have the ability to pay i.e. it does not tax those who do not reach a minimum threshold of wealth in their hands.

On the macroeconomic front, proportional Zakat linked with income acts as an automatic stabiliser. When aggregate personal disposable income increases in economic booms, more Zakat is collected and more amount is available to the government for increasing transfer payments to Fuqura (poor and needy), Masakeen (extremely poor and needy) and Gharimeen (borrowers in trouble). When aggregate personal disposable income decreases in recessions, obligatory Zakat also decreases and thereby providing an automatic relief to the income earners when the incomes decline.

Besides the proportional income levy, Zakat on wealth redistributes wealth and reduces wealth concentration. So, if an economy is in disequilibrium and policies fail to immediately recover and boost incomes, wealth Zakat enables the distributive allocation that works independently of the business cycles and help stabilise the extremes of the business cycles. In this way, wealth Zakat acts as a permanent stabiliser.

When the personal disposable incomes decline in recessions, more people will become eligible for Zakat. Since Zakat is levied on both income and wealth, the 
redistribution of wealth will always be functional and operative in an Islamic economy due to wealth Zakat. Transfer payments to the unemployed, poor, needy and debtors will continue even when the economy faces a recession.

Besides this, a consistent and credible low tax rate policy with broader Zakat base will help to minimise distortions, boost aggregate demand, encourage investment by decreasing costs of doing business and this could also simultaneously solve the microeconomic problems of imperfection in markets by increasing competition and reducing market power.

A uniform Zakat levy on wealth and produce can result in tax rate smoothing, stabilisation of business cycle and encourage long term investments and decision making without leaving the long term planner in the private sector to worry about fiscal policy reversals (i.e., Ricardian equivalence).

One possible question may arise here as to how such lenient tax rates would increase substantial public revenue. If the government has a fiscal deficit of 6 percent of GDP when corporate tax rates are 35 percent; then, how can reducing tax rates increase the revenue? The answer to this is given by the Laffer curve. Laffer (2004), a supply side economist, himself noted that Muslim philosopher Ibn Khaldun wrote about it in "The Muqaddimah".

Higher tax rates discourage entrepreneurship as they decrease the incentive to produce. Lower tax rates encourage entrepreneurship and hence increase the size of the production sector and hence production. With the increase in production, tax revenue in amount increases because of a larger base. Hence, lower tax rates can still ensure high tax to GDP ratio. This is evident from Table 6 which lists countries with corporate tax rates below 20 percent and their tax to GDP ratio.

Table 6

Corporate Tax Rate and Tax to GDP Ratio

\begin{tabular}{cccc}
\hline S. No. & Country & Tax to GDP Ratio & Corporate Tax Rate \\
\hline 1 & Chile & $17.1 \%$ & $17 \%$ \\
2 & Bulgaria & $34.4 \%$ & $10 \%$ \\
3 & Czech Republic & $36.3 \%$ & $21 \%$ \\
4 & Georgia & $21.7 \%$ & $15 \%$ \\
5 & Greece & $33.5 \%$ & $22 \%$ \\
6 & Hong Kong & $12.8 \%$ & $16.5 \%$ \\
7 & Hungary & $37.3 \%$ & $16 \%$ \\
8 & Iceland & $40.4 \%$ & $18 \%$ \\
9 & Ireland & $34 \%$ & $12.5 \%$ \\
10 & Kazakhstan & $26.8 \%$ & $15 \%$ \\
11 & Netherlands & $39.5 \%$ & $20 \%$ \\
12 & Poland & $33.8 \%$ & $19 \%$ \\
13 & Romania & $28.1 \%$ & $16 \%$ \\
14 & Russia & $36.9 \%$ & $20 \%$ \\
15 & Serbia & $34.1 \%$ & $10 \%$ \\
16 & Singapore & $13 \%$ & $17 \%$ \\
17 & Slovakia & $29.5 \%$ & $19 \%$ \\
18 & Switzerland & $30.1 \%$ & $13 \%-25 \%$ \\
19 & Turkey & $32.5 \%$ & $20 \%$ \\
20 & Uzbekistan & $21 \%$ & $12 \%$ \\
\hline Source International Tax and Business Guides- Economic Data - Statistics - Tax - EIU - The Economist.
\end{tabular}


If this system is enforced with sincerity by the government, along with the commitment of the general public and the public/private sector partnership, this can put an end to extreme poverty in Pakistan.

\subsection{Effects of Proposed Zakat System on Property Market}

In the proposed method, there will be a 10 percent income tax on the gain on sale of a property. If the gain on sale is less than 25 percent, the tax in amount will be more if the property is kept in ownership than when it is sold. This will increase the supply of land that was not presented for sale before. The increase in supply will bring the prices of properties down. Hence, affordable housing and commercial facilities will come in the reach of consumers and commercial enterprises respectively.

A simplified numerical example is presented below:

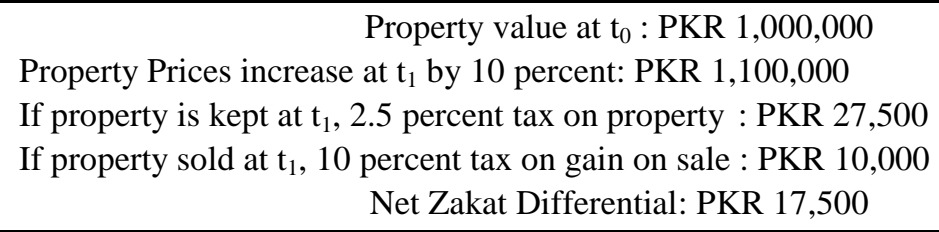

If the property owner does not want to sell the property and wants to use it in the future and also wants to benefit from the fiscal incentive, then he can give the property to someone on rental basis for use. He will retain the ownership, but it will be considered an investment and hence instead of wealth tax, 10 percent income tax will be charged on rental income.

\begin{tabular}{|} 
Property value at $\mathrm{t}_{0}:$ PKR $1,000,000$ \\
Assume that property is given for use on rental basis @ 10 percent/year of property \\
value
\end{tabular}

\subsection{Effects of Proposed Zakat System on Investment}

Private sector investors including both local and foreign investors have an essential role to play in achieving the desired growth and development targets in an Islamic economy. The goal is not only to redistribute the pie, but to increase the pie is well. The lenient tax rates will decrease the tax expense of firms and allow them to have more resources for reinvestment and profit distribution among shareholders in the form of dividends. Lenient tax rates could also help in increasing the inflow of FDI.

It can be seen from the illustration presented above that if any form of wealth is put into investment, its nature for fiscal treatment changes and tax saving of at least 2.5 percent results on the gross investment value. For instance, if there is no income on an investment, then still 2.5 percent tax saving results and no income tax is to be paid since there is no income. 


\subsection{Effects of Proposed Zakat System on Capital Markets}

In an interest free economy, the savers will have to make a choice between keeping their money idle and pay wealth tax or invest it in some asset or enterprise and pay the tax only on income if it is earned. A simplified numerical example is presented below:

\begin{tabular}{|c|}
\hline Value of Stock of Company A at $\mathrm{t}_{0}$ : PKR 100 \\
Stock Prices increase at $\mathrm{t}_{1}$ by 10 percent: PKR 110 \\
If no investment in stock or other assets, wealth Zakat will be $\quad$ : PKR 2.75 \\
If stock is owned and sold at $\mathrm{t}_{1}, 10$ percent tax on gain on sale will be : PKR 1 \\
Net Zakat Differential: PKR 1.75
\end{tabular}

In the proposed approach, if Return on Investment (RoI) is below 25 percent, less Zakat is to be paid in monetary terms as compared to wealth Zakat in the classical approach. If the shareholder does not want to sell the stock, but still wants to benefit from the fiscal incentive, he can keep the stock in ownership and pay tax only on dividend income. Purchase of stocks for capital gain/dividend will be considered as an investment and hence instead of wealth tax on full investment value, only 10 percent income tax will be charged on actual income earned. A simplified numerical example is presented below:

Value of Stock of Company A at $\mathrm{t}_{0}$ : PKR 100

Company $\mathrm{A}$ is profitable and pays 10 percent dividend

If no investment in stock or other assets, wealth Zakat will be : PKR 2.75

If stock is kept in ownership till $\mathrm{t}_{1}, 10$ percent tax on dividend : PKR 1

\section{Net Zakat Differential: PKR 1.75}

If Dividend Yield (DY) is 10 percent, less Zakat is paid in the proposed approach as compared to wealth Zakat in the classical approach. It shows that investment is encouraged rather than keeping idle wealth in an interest free economy in the presence of the institution of Zakat.

\section{CONCLUSION}

Islamic economics literature is rich in describing the welfare potential of Zakat, but very few empirical studies have undertaken the quantitative estimation of potential Zakat collection. In this study, we attempted to estimate potential Zakat collection at the economy wide level to document the welfare potential of the institution of Zakat. In our estimation exercise, we attempted to estimate economy wide Zakat collection by including heads like Zakat on agriculture produce, value of livestock, tradable inventory, currency in circulation, foreign exchange reserves, estimated gold and silver deposits and financial assets like investments in National Savings Scheme (NSS), mutual funds, stock market capitalization, pension schemes and bank deposits. Our estimates suggest that approximately Zakat collection in Pakistan could reach 7 percent of total GDP and is sufficient for covering poverty gap in Pakistan. We also discussed that the institution of 
Zakat system can also have positive effects on the flow of investment, promoting entrepreneurship culture and making capital markets and real estate markets more competitive and liquid. At the macroeconomic level, we also discussed the role of institution of Zakat as stabiliser and a countercyclical support mechanism to deal with welfare issues.

\section{REFERENCES}

A. Nadzri, A. Farah, Rashidah A. Rahman, and Nomrah Omar (2012) Zakat and Poverty Alleviation: Roles of Zakat Institutions in Malaysia. International Journal of Arts and Commerce 1:7, 61-72.

Abu Bakar, Nur B. A. Rahman, and A. Rahim (2007) A Comparative Study of Zakat and Modern Taxation. Journal of King Abdul Aziz University: Islamic Economics 20:1, $25-40$.

Ahmed, Habib (2004) Role of Zakat and Awqaf in Poverty Alleviation. Islamic Research and Training Institute. Islamic Development Bank Group, Jeddah. (Occasional Paper No. 8).

Azam, M., N. Iqbal, and M. Tayyab (2014) Zakat and Economic Development: Micro and Macro Level Evidence from Pakistan. Bulletin of Business and Economics 3:2, $85-95$.

Debnath, Sajit C., Mohammad T. Islam, and Kazi T. Mahmud (2013) The Potential of Zakat Scheme as an Alternative of Microcredit to Alleviate Poverty in Bangladesh. 9th International Conference on Islamic Economics and Finance QFIS, Doha, Qatar.

Hassan, M. K. (2010) An Integrated Poverty Alleviation Model Combining Zakat, Awqaf and Microfinance. In Seventh International Conference-The Tawhidi Epistemology: Zakat and Waqf Economy, Bangi, Malaysia.

Hassan, M. Kabir and Jauanyed Masrur Khan (2007) Zakat, External Debt and Poverty Reduction Strategy in Bangladesh. Journal of Economic Cooperation 28:4, 1-38.

Ibrahim, Patmawati (2006) Economic Role of Zakat in Reducing Income Inequality and Poverty in Selangor. PhD thesis, Universiti Putra Malaysia.

Khan, M. Akram (2005) Comments on A. Azim Islahi and M. Obaidullah: Zakat on Stocks: Some Unsettled Issues. Journal of King Abdul Aziz University: Islamic Economics 18:1, 41-42.

Kuran, Timur (2003) Islamic Redistribution through Zakat: Historical Record and Modern Realities. In M., Bonner, M. Ener, and A. Singer (eds.) Poverty and Charity in Middle Eastern Contexts. SUNY Press. 275-293, 275-276.

Laffer, A. B. (2004) The Laffer Curve: Past, Present, and Future. Heritage Foundation Backgrounder 1765.

M. Akram, Mian and M. Afzal (2014) Dynamic Role of Zakat in Alleviating Poverty: A Case Study of Pakistan. University Library of Munich, Germany.

Malik, Sohail J., Muhammad Hussain, and Nasim S. Shirazi (1994) Role of Infaq in Poverty Alleviation in Pakistan. The Pakistan Development Review 33:4, 935-952.

Maududi, Sayyid Abul A'la (1970) Ma'ashiyat-e Islam [Economic System of Islam]. Lahore: Islamic Publications.

Nadvi, S. Moeen-ud-din (1996) Taareekh-e-Islam [History of Islam]. Lahore: Maktaba-eRehmania. 
Naveed, Arif and Nizam Ali (2012) Clustered Deprivation-District Profile of Poverty in Pakistan, SDPI.

Powell, Russell (2009) Zakat: Drawing Insights for Legal Theory and Economic Policy from Islamic Jurisprudence. Pittsburgh Tax Review 7:43, 10-17.

Qaradawi, Yusuf al (1999) Fiqh az-Zakat: A Comparative Study-The Rules, Regulations and Philosophy of Zakat in the Light of the Qur'an and Sunnah. Dar Al Taqwa Ltd. London.

Sadeq, A. H. M. (1996) Ethico-Economic Institution of Zakat: An Instrument of Self Reliance and Sustainable Grassroots Development. IIUM Journal of Economics and Management 12:2.

Shirazi, Nasim S. (2014) Integrating Zakat and Waqf into the Poverty Reduction Strategy of the IDB Member Countries. Islamic Economic Studies 22:1, 79-108.

Shirazi, Nasim S. and M. Fouad Amin (2009) Poverty Elimination Through Potential Zakat Collection in the OIC-member Countries: Revisited. The Pakistan Development Review 48:4, 739-754.

Wahid, Abu N. M. (1986) The Economic Implications of Zakat. Contemporary Review 248:1440, p. 10.

Yusoff, Mohammed B. (2011) Zakat Expenditure, School Enrolment, and Economic Growth in Malaysia. International Journal of Business and Social Science 2:6, 175181. 